\title{
Radio-protective effect and mechanism of 4-Acetamido-2,2,6,6- tetramethylpiperidin- 1-oxyl in HUVEC cells
}

Feng Wang ${ }^{1,3+}$, Peng Gao ${ }^{1+}$, Ling Guo ${ }^{1}$, Ping Meng ${ }^{4}$, Yuexing Fan³ ${ }^{3}$ Yongbin Chen ${ }^{1}$, Yanyun Lin ${ }^{1}$, Guozhen Guo ${ }^{1}$, Guirong Ding ${ }^{1 *}$ and Haibo Wang ${ }^{2^{*}}$ (D)

\begin{abstract}
Objectives: To search for more effective radiation protectors with minimal toxicity, a water-soluble nitroxides Acetamido-Tempol (AA-Tempol) was evaluated for potential radioprotective properties in HUVEC cells (Human Umbilical Vein Endothelial cell line).

Methods: To study the anti-radiation effect of AA-Tempol in cell culture, the viability of irradiated HUVEC cells using a clonogenic survival assay was examined. The anti-apoptosis effects of AA-Tempol using Annexin $\mathrm{V} /$ propidium iodide staining in a flow cytometry assay was also evaluated. To elucidate the molecular mechanism of the anti-apoptosis effect of AA-Tempol against X-radiation induced HUVEC cell apoptosis, the expression of Bax, Bcl-2 and p53 and caspase-3 were examined. The changes in the level of malondialdehyde (MDA) and glutathione (GSH) in HUVEC cells after $X$-radiation were also investigated.

Results: Pretreatment of the HUVEC cells colony with AA-Tempol $1 \mathrm{~h}$ before X-radiation significantly increased the colony survival $(p<0.05)$ compared with the cells without pretreatment. This demonstrates that AA-Tempol provides an effective radiation protection in the irradiated HUVEC cells, thus reducing apoptosis from $20.1 \pm 1.3 \%$ in 8 Gy X-radiated cells to $12.2 \pm 0.9 \%\left(1.0 \mathrm{mmol} / \mathrm{L}^{-1} \mathrm{AA}\right.$-Tempol) in AA-Tempo pretreated HUVEC cells. This implies that 1. 0 mM AA-Tempol treatment significantly block the increase of caspase-3 activity in radiated HUVEC cells $(P<0.01)$, causing down-regulation in expressions of Bax and P53 and up-regulation in the expression of $\mathrm{BCl}$-2. Pretreatment with AA-Tempol also decreased the MDA activities $(P<0.01)$ and increase the GSH level $(P<0.05)$ in HUVEC cells compared to the $8 \mathrm{~Gy}$ X-radiated cells without pretreatment.
\end{abstract}

Conclusions: These observations indicate that AA-Tempol is a potential therapeutic agent against the radiation damage. Keywords: HUVEC cells, lonizing radiation, Antioxidative, Radioprotection, Tempol

\section{Introduction}

With the advent of new technologies, ionizing radiation (X- and gamma-rays) has been widely used in different fields during the last decades, both in every branch of medicine, to diagnostic and diseases treatment; and in several industries, where human exposure to ionizing radiation has increased tremendously [1, 2]. Ionizing

\footnotetext{
* Correspondence: dingzhao@fmmu.edu.cn; whb7691@163.com

${ }^{\dagger}$ Equal contributors

'School of Preventive Medicine, Fourth Military Medical University, Xi'an

710032, People's Republic of China

${ }^{2}$ School of Pharmacy, Fourth Military Medical University, Xi'an 710032,

People's Republic of China

Full list of author information is available at the end of the article
}

radiation causes damage to living tissues through a series of molecular events depending on the radiation energy. Its damaging effects and the intensity on human health have been reported [3]. Due to the hazardous effects of the ionizing radiation, the ability of some chemical compounds to protect cells from damaging effects of ionizing radiation has been reported. For instance, Patt et al. [4] made initial discovery about the protective effects of cysteine on the X-irradiation damage in mice. Other new agents, such as amifostine (WR2721) has been discovered and clinically approved by the Food and Drug Administration for reducing the side effects of 
radiotherapy in patients [5]. Several studies have also demonstrated that amifostine protects normal tissue from both acute and late radiation damage without protecting the tumor. In another term amifostine is a selective cytoprotector of normal tissues [6-9]. However, WR2721 has some side-effects such as hypotension, nausea, and vomiting, which are significantly augmented upon intravenous administration [10-12]. Hence, the development of effective and less toxic radioprotection agents is of great importance [13].

The biological effects of ionizing radiation are linked to the production of reactive oxygen species (ROS) in organisms which interact with critical macromolecules, such as DNA, proteins or membranes and lead to mutations and chromosomal aberrations [14]. The DNA damage is one of the most important side effects of ionizing radiation [15]. The ROS mediated bimolecular reactions and their relationship with radiation side effects are the current subject of scientific investigations in radiotherapy. To address this problem, some chemical agents have been investigated as scavengers of ROS, thus serve as effective radioprotectors againstzradiation damage [16]. Another benefit is their supplementation of antioxidants to improve the efficacy of radiotherapy. A wide range of phytochemicals that have been investigated for this purpose include, flavonoids, polyphenols, carotenoids, and organosulfur compounds [17].

In recent years, nitronyl nitroxide radicals have been extensively studied due to their antioxidative properties to protect against oxidative damage [18-20]. Nitronyl nitroxide radicals can directly react with ROS [21] to prevent the reduction of hydrogen peroxide to the hydroxyl radical [22], which occured through the redox transformations between the oxidation states of nitroxide, hydroxylamine, and the oxoammonium cation. The nitroxide and oxoammonium cation paired the redox couple. The redox couple which paired by nitroxide and oxoammonium cation can support catalytic processes via reversible one-electron redox reactions. The hydroxylamine can function as an efficient hydrogen atom donor and provide antioxidant defense [23]. Tempol (4-hydroxy-2,2,6,6-tetramethylpiperidine- $\mathrm{N}$-oxyl) represents this new family of nitroxides that act as an effective antioxidant in scavenging superoxide anions which has been shown to have protective effects against ionizing radiation $[24,25]$. Tempol has been shown to protects mammalian cells against radiation-induced cytotoxicity in vitro [26] and can afford protection in vivo against whole- body irradiation [27]. It was reported that a mitochondria-targeted nitroxide/hemigramicidin S conjugate (TPEY-Tempol) protected mouse embryonic cells against gamma irradiation significantly $[28,29]$. To search for more effective radiation protectors with minimal toxicity, a water-soluble nitroxides Acetamido-Tempol (AA-Tempol, Fig. 1) was evaluated for potential radioprotective properties using HUVEC cells and clonogenic assays. Its radioprotective effects in vitro were evaluated in this study. The results showed that AATempol increased the level of GSH and decreasing the level of MDA which acted as antioxidants by scanvenging ROS. The present data also showed that pretreatment with AA-Tempol can attenuated Xradition induced cell apoptosis by regulating the expression levels of Bcl-2, Bax, caspase-3 and P53. These observations indicate that AA-Tempol may be a potential therapeutic agent against the radiation damage.

\section{Material and methods \\ Chemicals}

4-Acetamido-2,2,6,6-tetramethylpiperidin-1-oxyl was purchased from Sigma (Beijing, China). All other chemical reagents were purchased from J\&K Scientific Ltd. (Beijing, China), and other chemicals and reagents were purchased from Sigma (Beijing, China), unless otherwise indicated. All chemicals and reagents used were commercially available and of standard biochemical quality.

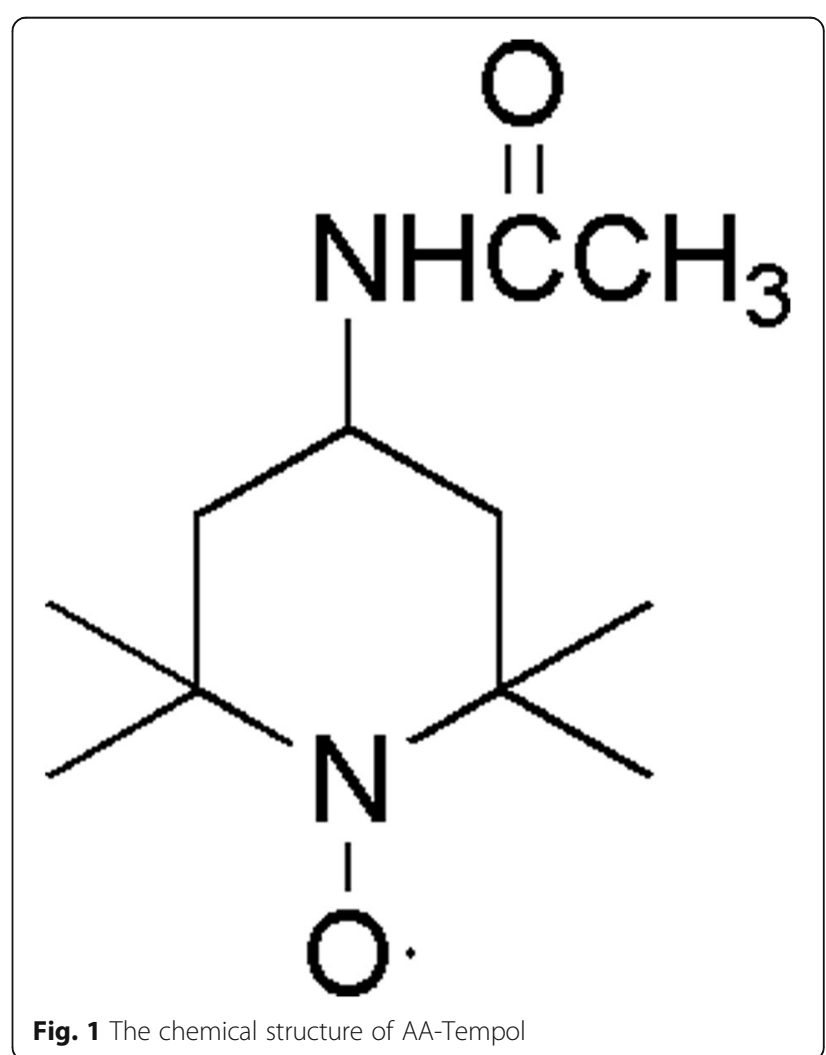




\section{Cells}

The Human Umbilical Vein Endothelial cell line (HUVEC) was provided by the Department of Preventive Medicine, the Fourth Military Medical University (No. 169, Changle West Road, Xi'an, Shaanxi 710032, PR China). They were grown at $37{ }^{\circ} \mathrm{C}$ in a humidity of $5 \%$ $\mathrm{CO}_{2}$ in Dulbecco's modified Eagle's medium (DMEM) supplemented with $10 \%$ fetal bovine serum, 10000 units/ $\mathrm{mL}$ penicillin and $50 \mu \mathrm{g} / \mathrm{mL}$ streptomycin.

\section{Cytotoxicity assay}

The cytotoxicity assays was performed by the Cell Counting Kit-8 (CCK-8) method [30]. HUVEC cells were seeded into 96-well plates at a density of $2 \times 10^{4}$ cells per well and incubated at $37{ }^{\circ} \mathrm{C}$ in a humidified atmosphere with $5 \% \mathrm{CO}_{2}$ for $24 \mathrm{~h}$. The medium was removed and fresh DMEM containing the appropriate dilution of the AA-Tempol was added. AA-Tempol were dissolved in $0.01 \mathrm{~mol} / \mathrm{L}$ Phosphate Buffered Saline(PBS, $\mathrm{pH} 7.4$ ) at $32 \mathrm{mmol} / \mathrm{L}$. HUVEC cells were seeded into 3 96-well plates at a density of $2 \times 10^{4}$ cells per well and incubated at $37{ }^{\circ} \mathrm{C}$ in a humidified atmosphere with $5 \% \mathrm{CO}_{2}$ for $24 \mathrm{~h}$. Then the medium was removed, the AA-Tempol solution and fresh DMEM were added at a final AATempol concentration of $0,0.0625,0.25,1,2,4,8$, $16 \mathrm{mmol} / \mathrm{L}$ respectively. Each concentration has 5 duplicate wells in one plates. After treatment for $0.5,1$ and $2 \mathrm{~h}$ respectively, HUVEC cells in the plates were cultured for another $48 \mathrm{~h}$ in fresh DMEM, then treated with Cell Counting Kit- 8 reagent $(10 \mu \mathrm{L} /$ well $)$ for $2 \mathrm{~h}$ at $37{ }^{\circ} \mathrm{C}$. The absorbance was read at $450 \mathrm{~nm}$. The experiments were performed at least three times.

\section{colony survival assay}

Colony survival assay was performed using Giemsa staining method as previously described [31]. Cells were seeded onto 6-well plates and allowed to grow for $24 \mathrm{~h}$ prior to treatment with different concentrations of the AA-Tempol. AA-Tempol was solubilised with $0.01 \mathrm{~mol} / \mathrm{L} \mathrm{PBS}$ and diluted in culture media to achieve concentrations of 0,1 and $2 \mathrm{mM}$. Control cells were prepared in a similar way except that the cell was not pretreated with AA-Tempol before irradiation. Irradiation ( 4 and $6 \mathrm{~Gy}$ ) was performed with a $\mathrm{X}$-ray machine at dose rate of $4.404 \mathrm{~Gy} / \mathrm{min}$. The serial dilution of AA-Tempol with DMEM media in cultured plates yielded final concentrations of $0,1,2 \mathrm{mM}$. The different concentrations of AA Tempol was added onto the cells at $1 \mathrm{~h}$ before $\mathrm{X}$-ray irradiation (0Gy,4Gy,6Gy). After 10 to 14 days incubation in fresh DMEM in a humidified atmosphere containing $5 \% \mathrm{CO}_{2}$, the plates were fixed with $70 \% \mathrm{MeOH}$ and stained with $0.8 \%$ Swiss Giemsa. And colonies which come from an original surviving cell of 50 or more cells were counted as survivors. The surviving fractions were calculated as the plating efficiency of samples relative to that of shamirradiated control. The survival fractions were calculated as (number of colonies/number of cells plated)/(number of colonies for corresponding sham-irradiated control/ number of cells plated) [32]. The experiment was performed at least six times.

\section{Hoechst staining}

Cell death was determined by Hoechst 33258 (Sigma) fluorescent staining. Cell suspensions were seeded into 24-well plates at a concentration of $2 \times 10^{4}$ cells per well. Cells were allowed to attach for $24 \mathrm{~h}$; and then treated with $2 \mathrm{mM}$ AA-Tempol for $1 \mathrm{~h}$ before $\mathrm{x}$ radiation (0 and $8 \mathrm{~Gy}$ ). The cells were washed with PBS for three times at $0.5 \mathrm{~h}$ after X-ray irradiation and then incubated for $48 \mathrm{~h}$ with DMEM. Then the cells were stained with Hoechst $33258(10 \mu \mathrm{g} / \mathrm{ml})$ for $15 \mathrm{~min}$, and then fixed by $4 \%$ paraformaldehyde for $10 \mathrm{~min}$. Cells were observed under a fluorescence microscope (Olympus BX61, Japan). The Hoechst dye were excited at $340 \mathrm{~nm}$. For each well, three visual fields were selected randomly.

\section{Flow cytometric (FCM) analysis of the cell apoptosis}

Apoptosis analyses were performed as described previously [33]. Briefly, apoptosis and cell viability were measured by using annexin V-FITC (Assay Designs, Inc. USA) and PI double staining. HUVEC cells were seeded into $10 \mathrm{~cm}$ plates at a density of $5 \times 10^{5}$ cells per well and allowed to grow for $24 \mathrm{~h}$ prior to treatment with AA-Tempol. Then AA-Tempol was added to cultured cells maintaining the final concentration of $1.0 \mathrm{mmol} \cdot \mathrm{L}$ ${ }^{-1}$ for $1 \mathrm{~h}$ before $8 \mathrm{~Gy} \mathrm{X}$-radiation. At $0.5 \mathrm{~h}$ after radiation, the medium was removed and fresh DMEM was added onto HUVEC cells. The untreated cells (blank control) as well as the treated cells were incubated for 4 days. Then cells were harvested and washed twice with $0.01 \mathrm{~mol} / \mathrm{L}$ PBS. Before they were measured by flow cytometer, ethanol was washed off with PBS. The cells were diluted in $100 \mu \mathrm{l}$ of $1 \times$ annexin-binding buffer per assay and incubated with annexin V-FITC and PI for $15 \mathrm{~min}$ at room temperature in the dark. Having been washed with PBS, they were measured by Epics XL-4 flow cytometer (BECKMAN-Coulter, USA) using Cellquest software (version2) to obtain the information on apoptosis.

\section{Western blot analysis}

Western blot analysis was performed as described previously [34]. Cultured cells were preincubated with the concentrations of AA-Tempol $\left(1.0 \mathrm{mmol} \cdot \mathrm{L}^{-1}\right)$ at $37{ }^{\circ} \mathrm{C}$ for $1 \mathrm{~h}$, then cells were exposed to $8 \mathrm{~Gy} \mathrm{X}$-radiation and cultured for $48 \mathrm{~h}$ in fresh DMEM. Protein concentrations 
were determined by using the BCA assay kit. Proteins of total extracts were separated on 10\% SDS gels. Separated proteins were transferred electrophoretically onto polyvinylidene difluoride membrane (PVDF) (Amersham International) and blocked with 5\% non-fat milk in phosphate buffered saline (PBS)-Tween for $2 \mathrm{~h}$. The primary antibodies polyclonal rabbit anti-Bcl-2 (dilution ratio 1:2000), anti-p53 (dilution ratio 1:2000), anti- caspase3 (dilution ratio 1:3000), GAPDH (1:5000) and with $\beta$-actin (dilution ratio 1:3000) were incubated with the membranes at $4{ }^{\circ} \mathrm{C}$ overnight. The membranes were incubated with a secondary antibody conjugated to horseradishperoxidase (Beyotime) after being washed with TBST three times for 10 min each time, and bands were visualized using an ECL system (Perkin Elmer). Semi-quantitation of scanned films was performed using Quantity One-4.6.2 (Bio-Rad, Italy). The relative expression levels of the targeted proteins were determined using beta-actin as a loading control. All western blots were independently replicated three times.

\section{Biochemical assays}

Cultured cells were pretreated with varied concentrations of AA-Tempol $\left(0,0.25,1,4 \mathrm{mmol} \cdot \mathrm{L}^{-1}\right)$ at $37{ }^{\circ} \mathrm{C}$ for $1 \mathrm{~h}$ before 8 Gy X-radiation and cultured for another $48 \mathrm{~h}$ in fresh DMEM, then cells were harvested and suspended in $0.2 \mathrm{ml}$ PBS containing $0.1 \mathrm{ml}$ RIPA lysis buffer $(50 \mathrm{mM}$ Tris, $150 \mathrm{mM} \mathrm{NaCl}, 1 \%$ Triton X-100, $1 \%$ sodium deoxycholate, $0.1 \%$ SDS, sodium orthovanadate, sodium fluoride, EDTA, leupeptin, $1 \mathrm{mM}$ PMSF) and intermittently vortexed for $10 \mathrm{~min}\left(4^{\circ} \mathrm{C}\right)$ and centrifuged at $12,000 \times \mathrm{rpm}$ for $10 \mathrm{~min}\left(4^{\circ} \mathrm{C}\right)$. The supernatant was taken for biochemical estimations. The level of lipid peroxidation (MDA) was assayed by analyzing TBA-reactive substances which were determined by a method utilizing the lipid peroxidation assay kit. The pink-colored chromogen formed by the reaction of TBA with breakdown products of lipid peroxidation was measured [35]. The contents of reduced glutathione (GSH) were assayed by the commercially available cellular GSH assay kit. In each group, six samples $(n=6)$ were processed. The cell protein was determined by the Lowry method using BSA as standard. The experiment was performed at least six times.

\section{Statistical analysis}

The statistical analysis of the data to determine significant variations between the groups was performed using SPSS statistical software. The one-way analysis of variance (ANOVA) test was performed, and post hoc multiple comparisons were performed using the least significant difference (LSD) test. The results are presented as the means \pm standard deviation (SD). In all cases, $P<0.05$ was considered to indicate a statistically significant difference.

\section{Results}

Cytotoxicity and clonogenic protection of AA-Tempol

The cytotoxicity of AA-Tempol on HUVEC cells was examined using the CCK-8 assay. As shown in Fig. 2, AA-Tempol did not inhibit cell growth under the concentration of $4 \mathrm{mM}$ when exposed for $0.5 \mathrm{~h}$ and $1 \mathrm{~h}$. But when treated with the concentration of 8 and $16 \mathrm{mM}$ AA-Tempol for 0.5 and $1 \mathrm{~h}$, the optical density (OD) value of HUVEC cells decreased dramatically which indicated that the higher concentrations of AA-Tempol inhibited the cell growth greater than those with lower concentration $(P<0.05)$. When exposure for $2 \mathrm{~h}$ in $2,4,8$ and $16 \mathrm{mmol} / \mathrm{L}$ AATempol, the HUVEC cells growth were significantly

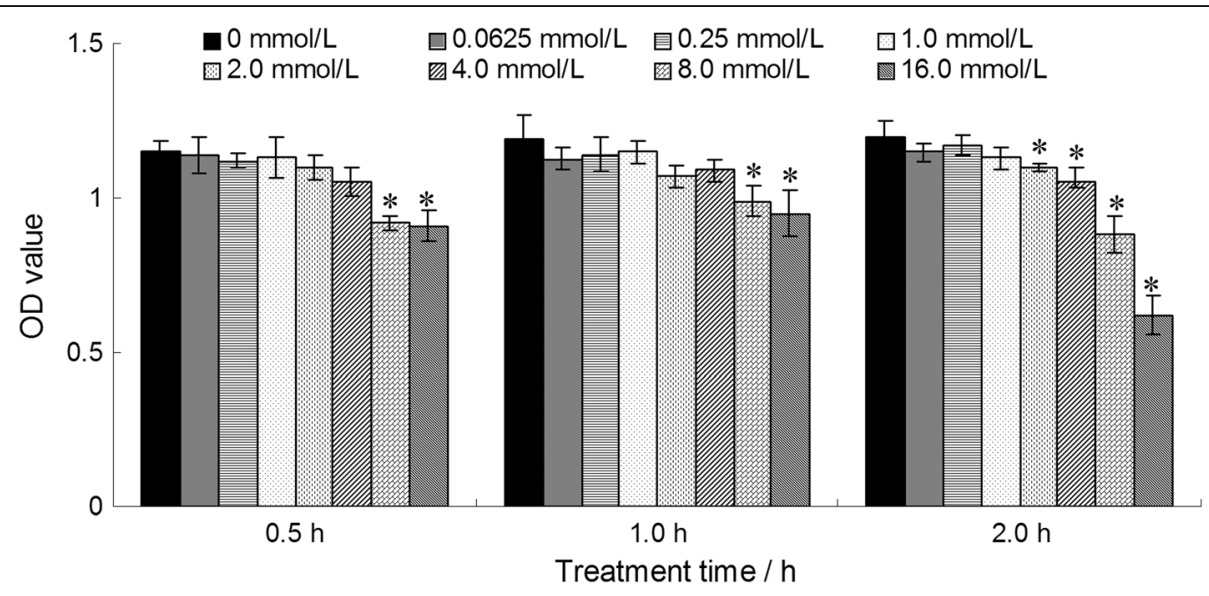

Fig. 2 The cytotoxicity of different concentrations $\left(0,0.0625,0.25,1,2,4,8\right.$ and $\left.16 \mathrm{mmol} \cdot \mathrm{L}^{-1}\right)$ of AA-Tempol exposure for $0.5,1$, and $2 \mathrm{~h}$ on HUVEC cells was examined by CCK-8 assay. The cells treated with $0.0625,0.25,1,2,4 \mathrm{mmol} \cdot \mathrm{L}^{-1}$ AA-Tempol for 0.5 and $1 \mathrm{~h}$ did not displayed cell growth inhibition. The cells treated with 8 and $16 \mathrm{mmol} \cdot \mathrm{L}^{-1} \mathrm{AA}$-Tempol exposure for 0.5 and $1 \mathrm{~h}$ and $2,4,8$ and $16 \mathrm{mmol} \cdot \mathrm{L}^{-1} \mathrm{AA}-\mathrm{Tempol}$ exposure for $2 \mathrm{~h}$ displayed mild cell growth inhibition. ${ }^{*} P<0.05 \mathrm{vs}$. normal control group 


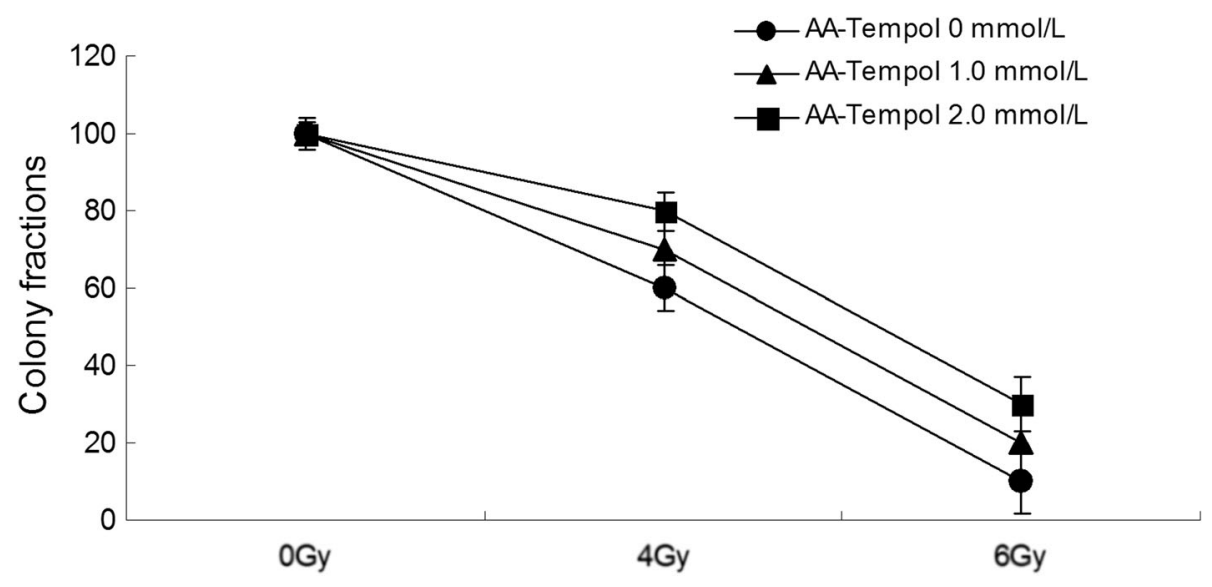

Fig. 3 The radioprotective effect of AA-Tempol on the viability of irradiated HUVEC cells was examined using clonogenic survival assay. Pretreatment of different concentrations $\left(0,1\right.$ and $\left.2 \mathrm{mmol} \cdot \mathrm{L}^{-1}\right)$ of AA-Tempol $1 \mathrm{~h}$ prior to X-radiation provided significant protection compared to cells treated with radiation alone $(P<0.05)$

inhibited $(P<0.05)$. Therefore, the radioprotection effects of being exposed for $1 \mathrm{~h}$ in $0.25,1,2,4 \mathrm{mmol} /$ L AA-Tempol were investigate on HUVEC cells.

To study the anti-radiation effect of AA-Tempol in cell culture, we examined the viability of irradiated HUVEC cells using a clonogenic survival assay. As shown in Fig. 3, pretreatment with AA-Tempol $1 \mathrm{~h}$ before X-radiation increased the colony survival $(P<$ 0.05) significantly compared with the cells treated with radiation alone. The maximum protection was achieved at $2.0 \mathrm{mmol} \cdot \mathrm{L}^{-1} \mathrm{AA}-\mathrm{Tempol}$ with radiation at 4 Gy $(P<0.05)$.

\section{Protective effects against apoptosis of AA-Tempol}

We evaluated the anti-apoptosis effects of AA-Tempol on HUVEC cells using Annexin V/propidium iodide staining in a flow cytometry assay. The results showed that X-Ray radiation dramatically increased the number of apoptotic cells compared with the normal control group. Pretreatment of HUVEc cells with
AA-Tempol pretreatment significantly reduced the radiation-induced apoptosis in HUVEC cells compared to the $8 \mathrm{~Gy} \mathrm{X}$-radiated cells $(P<0.01)$ (Figs. 4 and 5). This implies that AA-Tempol demonstrated a protective effect in irradiated HUVEC cells, thus reducing apoptosis from $20.1 \pm 1.3 \%$ in 8 Gy $\mathrm{X}$ radiated cells in untreated or control cells to $12.2 \pm$ $0.9 \%$ in cells treated with $1 \mathrm{mM}$ AA-Tempol). This suggests that the radioprotective effect of AA-Tempol in HUVEC cells was due to the attenuation of radiation-induced apoptosis.

\section{AA-Tempol upregulated $\mathrm{BCl}-2$ expression and downregulated P53, Bax and caspase-3 expression}

To elucidate the molecular mechanism of the antiapoptosis effect of AA-Tempol against X-radiation induced HUVEC cell apoptosis, the expression of Bax, Bcl-2 and p53 and caspase- 3 were examined as shown in Fig. 6. The results showed that X-radiation induced a sharp increase in P53, Bax and the active

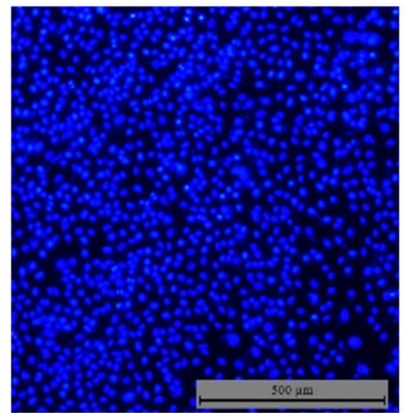

Normal cells

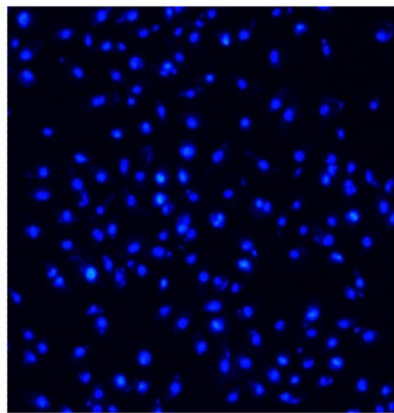

8Gy group

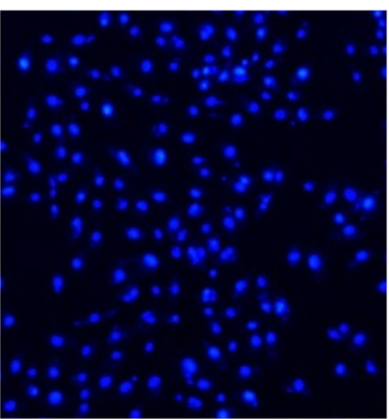

$8 \mathrm{~Gy}+2 \mathrm{mmol} \cdot \mathrm{L}^{-1} \mathrm{AA}-\mathrm{Tempol}$

Fig. 4 Hoechst 33258 and PI staining in cultured HUVEC cells. Representative fluorescence images obtained after Hoechst 33258 staining in Normal group, 8Gy X-radiation treated group, 8Gy X-radiation $+2 \mathrm{mmol} \cdot \mathrm{L}^{-1} \mathrm{AA}$-Tempol treated group 


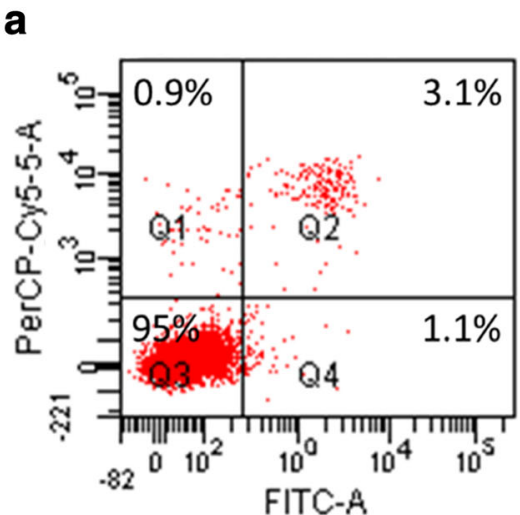

Normal group

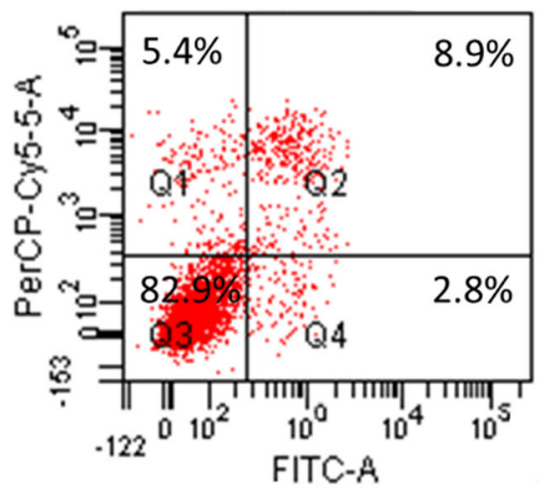

8 Gy

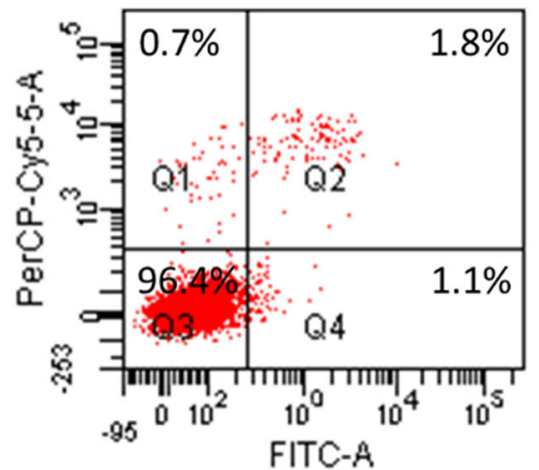

1.0 $\mathrm{mmol} \cdot \mathrm{L}^{-1}$ AA-Tempol

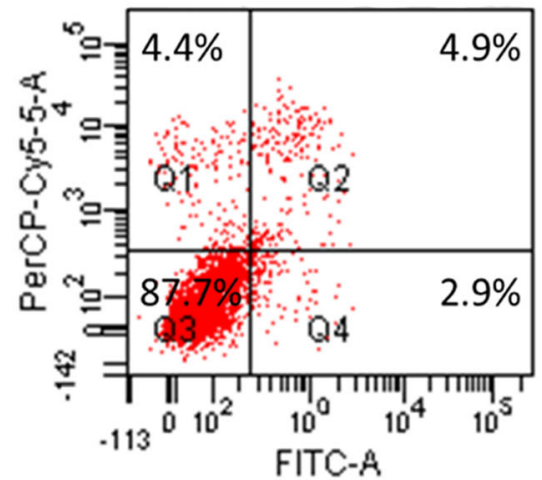

$8 G y+1.0 \mathrm{mmol} \cdot \mathrm{L}^{-1}$ AA-Tempol

b

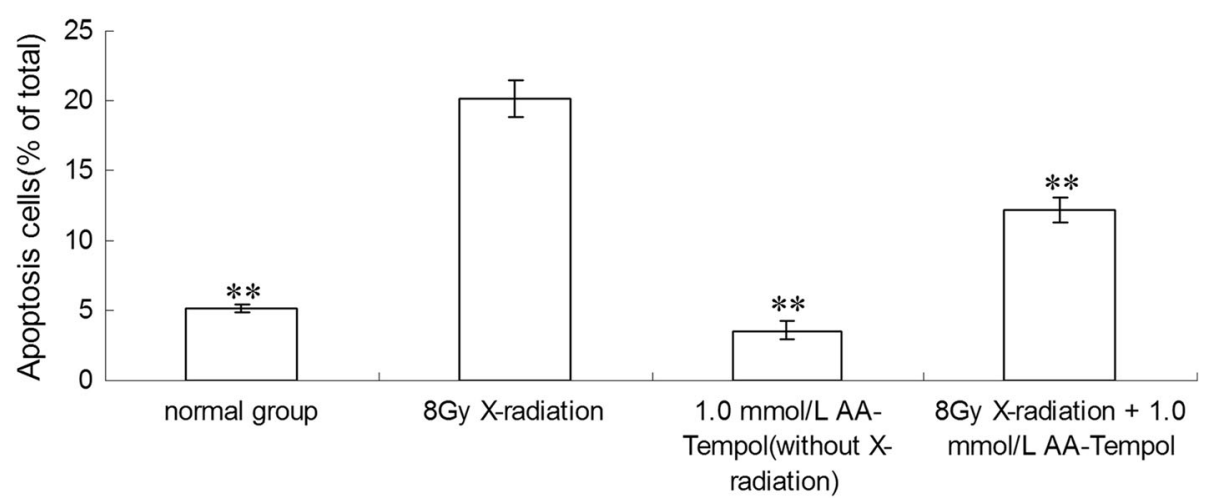

Fig. 5 The anti-apoptosis effect of different concentrations $\left(0,0.25,1,4 \mathrm{mmol} \cdot \mathrm{L}^{-1}\right)$ of AA-Tempol pretreatment for $1 \mathrm{~h}$ was analyzed using Annexin V/propidium iodide staining in a flow cytometry assay. a AA-Tempol pretreatment attenuated radiation-induced apoptosis in HUVEC cells. b The bar graph of apoptotic cells expressed as a percentage of total cells for each treatment with SAA from six experiments. Data are presented as mean \pm S.D. $(n=6) .{ }^{* *} P<0.01$ vs. 8 Gy group. Q1, Q2, Q3 and Q4 represent dead, late apoptosis, vital and early apoptosis cells, respectively

fragment of caspase 3 expression and a marked decrease in Bcl-2 expression. Compared with the control group, AA-Tempol treatment can significantly block the increase of caspase-3 activity in radiated HUVEC cells $(P<0.01)$. The expressions of Bax and P53 were also down-regulated and the expression of
Bcl-2 was up-regulated in the $1.0 \mathrm{mM}$ AA-Tempol pretreatment groups.

\section{Biochemical markers}

The changes in the level of malondialdehyde (MDA) and glutathione (GSH) in HUVEC cells after X-radiation are 


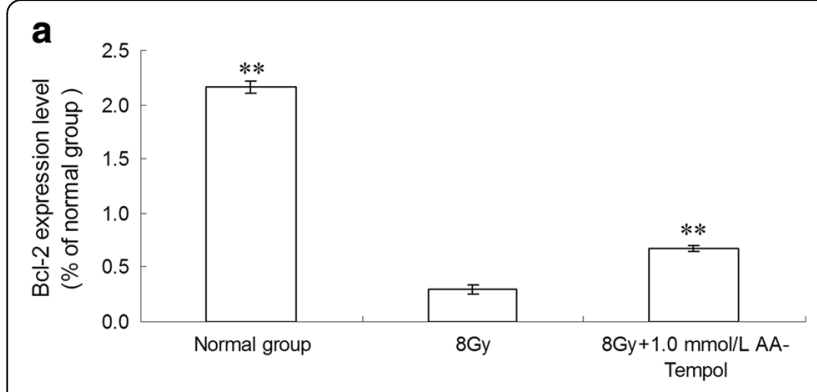

C

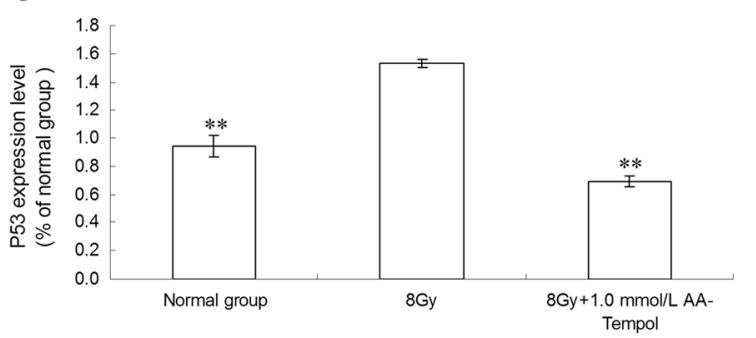

d

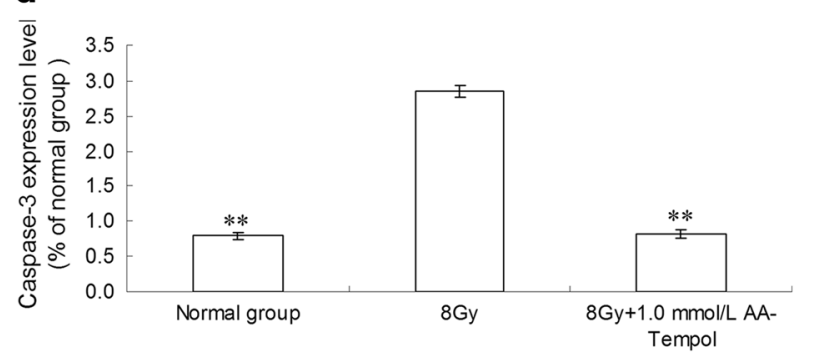

Fig. 6 The effect of AA-Tempol on the protein expressions of Bax, Bcl-2, P53 and caspase-3 in HUVEC cells was determine by immunoblotting assay $(\mathbf{a}, \mathbf{b}, \mathbf{c}, \mathbf{d})$ Semi-quantified data for the level of the proteins are shown in the lower panel $(\mathbf{e})$. Data represent mean \pm S.D. $(n=6)$. ${ }^{*} P<0.01$ vs. 8 Gy group

presented in Fig. 7. The results showed that X-radiation caused a dramatic decrease in GSH level and a significantly increase in MDA activity compared to the normal control group $(P<0.01)$. Pretreatment with AA-Tempol can decrease MDA activities $(P<0.01)$ and increase the GSH level $(P<0.05)$ in HUVEC cells significantly compared to the $8 \mathrm{~Gy} \mathrm{X}$-radiated cells.

\section{Discussion}

The present study was to evaluate the effects of Xradiation on the antioxidant defence system and the radioprotection afforded by AA-Temopl. The radiation energy causes damage to living tissues through a series of molecular events depending on developing reactive oxygen species (ROS) which are generated by the action of radiation on water. The major free radicals formed upon aqueous radiolysis are hydroxyl radical $(. \mathrm{OH})$ and superoxide radical $\left(\mathrm{O}^{-2-}\right)$ [36]. It has been reported that ionising radiation at cellular level induces damage in the biologically important macromolecules such as proteins, lipids, as well as nucleic acids [37]. Approximately 65\% of the DNA damage is caused by the indirect effect of these free radicals [38] and trigger the oxidation of biomolecules leading to the formation of various secondary free radicals, which can chemically modify DNA, proteins, and lipids, resulting in further cellular damage [39]. Therefore, antioxidants potentially provide protection from radiation.

It was reported that Tempol-treated TK6 human lymphoblastoid cells, which were known to undergo apoptosis in response to radiation exposure, demonstrated a decrease in cytotoxicity after exposure to a 6-Gy dose of ionizing radiation [40]. In a related experiment, nitroxides were found to protect against lipid peroxidation [41]. An early radioprotection study showed that the administration of Tempol to Chinese hamster cells exposed in culture to lethal doses of gamma-radiation resulted in a significant and dose-dependent protective effect with a protection factor of 2.5 compared to the untreated cells. Stephen M. Hahn reported two Tempol derivatives, Tempamine and 3-aminomethyl-PROXYL, exhibited greater radioprotection than Tempol [42]. A phase I clinical trial in patients receiving whole brain radiotherapy suggested that Tempol may be effective at preventing radiation-induced alopecia with only mild (grade I and II) toxicity [43].

It is known that GSH plays an important role in the antioxidation of reactive oxygen species (ROS) and free radicals [44-46]. It is a potent free radical and reactive oxygen species scavenger [47]. Irreversible cell damage supervenes when the cell is no longer able to maintain its $\mathrm{GSH}$ content [48]. In the present study, we found that $\mathrm{X}$-radiation caused a dramatic decrease in the level of GSH and an increase in the activity of MDA in HUVEC cells compared with the normal group $(P<$ $0.01)$, which showed that X-radiation can damage the redox balance. It has been reported Tempol can increased cell survival and protected against DNA damage induced by the mutagen neocarzinostatin (NCS), which had previously been shown to induce its mutagenic activity via a GSH-dependent mechanism [49]. We found that when pretreatment with AA-Tempol, a 

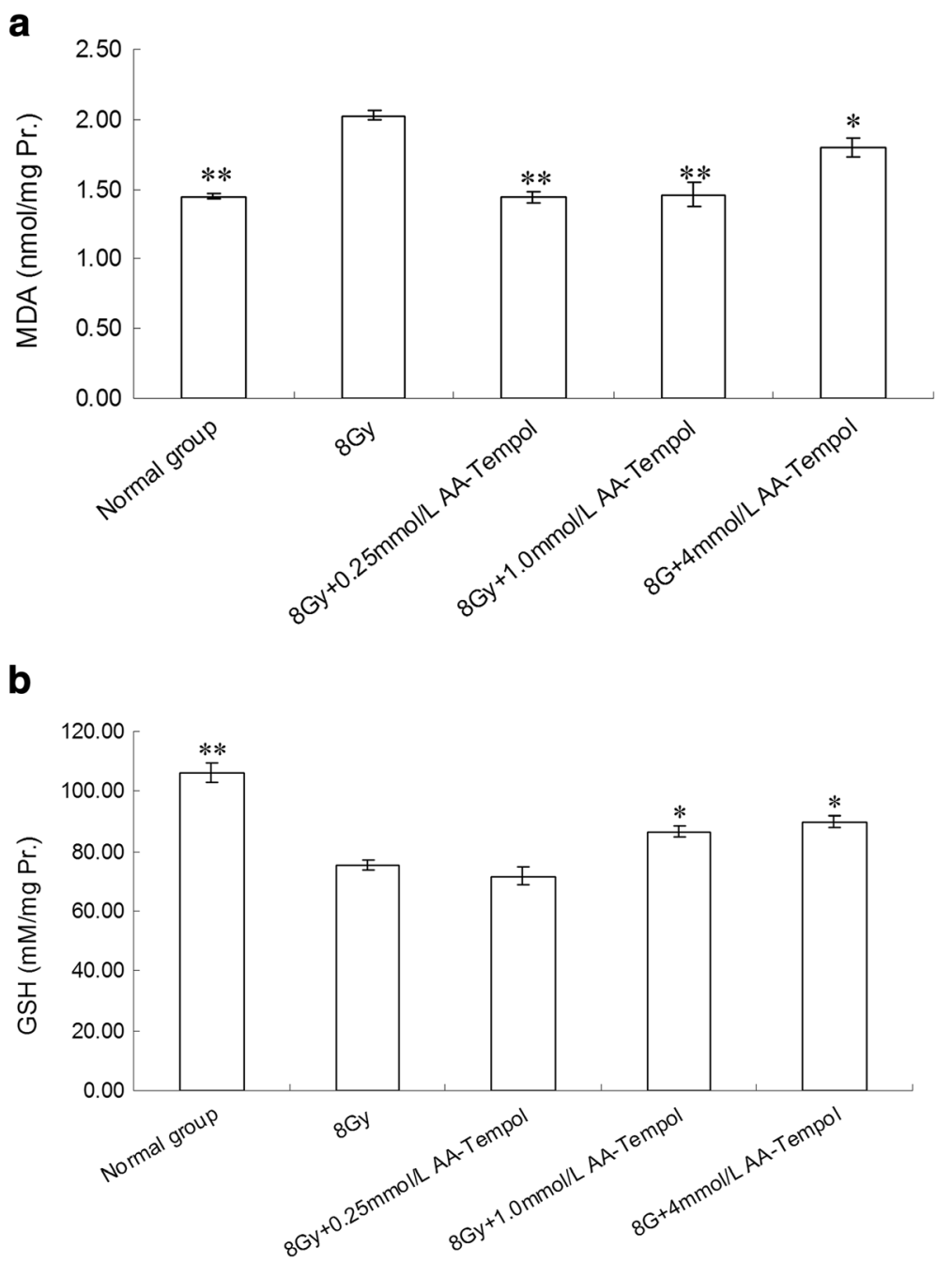

Fig. 7 The effect of AA-tempol on the activity of the level of MDA (a) and GSH (b) in HUVEC cells * $P<0.05$, ** $P<0.01$ vs. normal group

derivative of Tempol, significantly decreased the activitiy of MDA and increased the GSH level in HUVEC cells compared with the control group (without AATempol pretreatment, $P<0.05)$. This confirms that AA-Tempol provids protective effects against Xradiation damage through mediate the antioxidation system in vitro.

Induction of apoptosis by ionizing radiation is one of the mechanisms implicated in radiation-induced cytotoxicity. During apoptosis induction, many different activation cascades eventually lead to caspase-3 cleavage and subsequent cell death [50]. For instance, our previous studies have revealed that radiation induced apoptosis by the release of mitochondrial cytochrome $\mathrm{C}$, increasing the activation of caspase- 3 , and up regulating the expression of Bax and P53 and down regulating the expression of $\mathrm{Bcl}-2$ [51]. Proteins in the $\mathrm{Bcl}-2$ protein family are important in the regulation of cell apoptosis. Bcl-2 prevents the opening of the mitochondrial membrane pores and is the most important antiapoptotic gene [52], whereas Bax induces the opening of membrane pores and is a very important proapoptotic gene [53]. Under the oxidative stress, the transcription factor p53 is activated and stabilized. Subsequently, p53 up regulates the expression of genes that facilitate apoptosis, DNA repair or genomic stability [54]. In the present study, the results showed that X-radiation dramatically increased the numbers of apoptotic cells and induced a sharp increase in the Bax, caspase- 3 and P53 expression levels and a marked decrease in the $\mathrm{Bcl}-2$ expression level compared with the normal control group. The cell apoptotic death in by radiation is associated with the elevated production of ROS. Supplementation of antioxidants to improve the efficacy of radiotherapy is today's proposed strategy [55]. For instance, Samuni AM found that Tempol could prevent cell death in lymphoblastoid cells, which undergo apoptosis in 
response to radiation exposure and inhibit a radiation-induced increase in p53 observed in untreated control cells [40]. Our research indicated that in HUVEC cells, preatrement of AA-Tempol upregulated the expression of $\mathrm{Bcl}-2$ and down-regulated the expressions of Bax, caspase-3 and P53 after Xradiation exposure. The ability of AA-Tempol to attenuate cell apoptosis and regulate the expression levels of Bcl-2, Bax, caspase-3 and P53 may be due to its antioxidative capacity, which prevents the accumulation of ROS and other toxic materials to prevents the induction of cell death.

We believe that the mechanism of AA-Tempol to protect against ionizing radiation may due to its unique ability to scavenge the ROS. AA-Tempol belongs to nitroxides, are chemical compounds containing the tertiary amine $\left(\mathrm{R}_{3} \mathrm{~N}^{+}-\mathrm{O}^{-}\right)$functional group that are oxidized to form relatively stable nitroxide radicals. These compounds are membrane-permeable radical scavengers which have SOD and catalase activities though an oxoammonium/nitroxide redox couple [56-58]. Firstly, nitroxide radical RR'NO is converted to the oxoammonium cation $\left(\mathrm{RR}^{\prime} \mathrm{NO}^{+}\right)$by the oxidation of protonated form of superoxide $\left(\mathrm{HO}_{2}\right)$ [59]. Then $\mathrm{RR}^{\prime} \mathrm{NO}^{+}$can be reduced by $\mathrm{O}_{2}^{--}$back to the nitroxide radical.

$\mathrm{RR}^{\prime} \mathrm{NO} \cdot+\mathrm{O}_{2}^{--}+2 \mathrm{H}+\rightarrow\left[\mathrm{RR}^{\prime} \mathrm{NO}^{+}\right]+\mathrm{H}_{2} \mathrm{O}_{2}$

$\left[\mathrm{RR}^{\prime} \mathrm{NO}^{+}\right]+\mathrm{O}_{2}^{--} \rightarrow \mathrm{RR} \mathrm{RO}^{\prime}+\mathrm{O}_{2}$

In the whole process, the nitroxide acts as a catalyst and is not consumed in the process of dismutation of $\mathrm{O}_{2}$ - to $\mathrm{H}_{2} \mathrm{O}_{2}$ and oxygen. Furthermore, nitroxides and hydroxylamines can inhibit lipid peroxidation by participating in redox reactions at every step [60]. Additionally, nitroxides were shown to confer catalase-like behavior to heme proteins and to detoxify $\mathrm{H}_{2} \mathrm{O}_{2}$ [61] and to participate in radical-radical recombination reactions, which can limit the levels of free radicals and protect cells [62].

In conclusion, the protective effect of AA-Tempol for the antioxidant defenses in HUVEC cells was investigated. The results indicated that AA-Tempol increased the level of GSH and decreasing the level of MDA which acted as antioxidants by scanvenging ROS. The present data also showed that pretreatment with AA-Tempol can attenuated X-radition induced cell apoptosis by regulating the expression levels of Bcl-2, Bax, caspase-3 and P53. These observations indicate that AA-Tempol may be a potential therapeutic agent against the radiation damage.

\section{Acknowledgments}

We thank the National Science and Technology Support Program of China (No. 2013BAK03B05) the Natural Science Foundation of China (grant No. $31170798,51437008,81001398,21202202,81302695,21172261)$ and the Natural Science Foundation of Shanxi Province (2014JM2-2011) for a financial support.

\section{Authors' contributions}

FW and PG carried out the anti-radiation study and drafted the manuscript. LG carried out the Cytotoxicity assay and Western Blot
Analysis. PM performed the statistical analysis. YF carried out the Biochemical assays. YC and YL carried out the Hoechst Staining and Flow cytometric analysis. GG participated in the design of the study. HW and GD conceived of the study and participated in its design and coordination. All authors read and approved the final manuscript.

\section{Competing interest}

The authors declare that they have no competing interests.

\section{Publisher's Note}

Springer Nature remains neutral with regard to jurisdictional claims in published maps and institutional affiliations.

\section{Author details}

${ }^{1}$ School of Preventive Medicine, Fourth Military Medical University, Xi'an 710032, People's Republic of China. ${ }^{2}$ School of Pharmacy, Fourth Military Medical University, Xi'an 710032, People's Republic of China. ${ }^{3}$ Shanxi Province Corps Hospital, Chinese People's Armed Police Forces, Taiyuan 030006, People's Republic of China. ${ }^{4}$ Department of urology, Xijing Hospital, Fourth Military Medical University, Xi'an 710032, People's Republic of China.

Received: 20 July 2016 Accepted: 4 March 2017

Published online: 24 March 2017

\section{References}

1. Kuwahara Y, Li L, Baba T, Nakagawa H, Shimura T, Yamamoto Y, Ohkubo Y, Fukumoto M. Clinically relevant radioresistant cells efficiently repair DNA double-strand breaks induced by X-rays. Cancer Sci. 2009;4:747-52.

2. Greaves ED, Manz A. Toward on-chip X-ray analysis. Lab Chip. 2005;5:382-91.

3. Foray $\mathrm{N}$, Bourguignon $\mathrm{M}$, Hamad N. Individual response to ionizing radiation, Mutat. Res.: Rev Mutat Res. 2016;770(Part B):369-86.

4. Patt HM, Tyree EB, Straube RL, Smith DE. Cysteine Protection against $X$ Irradiation. Science. 1949;110:213.

5. Cakmak G, Miller LM, Zorlu F, Severcan F. Amifostine, a radioprotectant agent, protects rat brain tissue lipids against ionizing radiation induced damage: an FTIR microspectroscopic imaging study. Arch Biochem Biophys. 2012;5:2067-73.

6. Burkon P, Petyrek P, Spurny V. Cytoprotective effects of amifostine in the treatment of tumors. Vnitr Lek. 2003;49(8):673-8.

7. Koukourakis MI. Amifostine: is there evidence of tumor protection. Semin Oncol. 2003:30:18-30

8. Wasserman TH. Radioprotective effects of amifostine. Semin Oncol. 1999;26(2):89-94.

9. Wasserman TH, Brizel DM. The role of amifostine as a radioprotector. Oncol. 2001;15(10):1349-54

10. Bonner HS, Shaw LM. New dosing regimens for amifostine: a pilot study to compare the relative bioavailability of oral and subcutaneous administration with intravenous infusion. J Clin Pharmacol. 2002;42:166-74.

11. Cassatt DR, Fazenbaker CA, Bachy CM, Hanson MS. Preclinical modeling of improved amifostine (ethyol) use in radiation therapy. Sem Radiat Oncol. 2002;12:97-102.

12. Schuchter LM, Hensley ML, Meropol NJ, Winer EP. Update of recommendations for the use of chemotherapy and radiotherapy protectants: clinical practice guidelines of the American society of clinical oncology. J Clin Oncol. 2002;20:2895-903.

13. Koukourakis MI, Kyrias G, Kakolyris S, Kouroussis C, Frangiadaki C, Giatromanolaki A, Retalis G, Georgoulias V. Subcutaneous administration of amifostine during fractionated radiotherapy: a randomized phase II study. J Clin Oncol. 2000;18:2226-33.

14. Laurent A, Blasi F. Differential DNA damage signalling and apoptotie threshold correlate with mouse epiblast-specific hypersensitivity to radiation. Development. 2015;142(21):3675-85.

15. Riley PA. Free radicals in biology: oxidative stress and the effects of ionizing radiation. Int J Radiat Biol. 1994;65:27.

16. Jagetia GC, Baliga MS, Malagi KJ, Sethukumar Kamath M. The evaluation of radioprotective effect of Triphala (an ayurvedic rejuvenating drug) in the mice exposed to gamma irradiation. Phytomedicine. 2002;9:99-108.

17. Weiss JE, Landauer MR. Radioprotection by antioxidants. Ann N Y Acad Sci. 2000;899:44-60 
18. Kinoshita Y, Yamada K, Yamasaki T, Mito F, Yamato M, Kosem N, Deguchi H, Shirahama C, Ito Y, Kitagawa K, Okukado N, Sakai K, Utsumi H. In vivo evaluation of novel nitroxyl radicals with reduction stability. Free Radic Biol Med. 2010:49:1703-9.

19. Pliss EM, Tikhonov IV, Rusakov Al. The kinetics and mechanism of reactions of aliphatic stable nitroxyl radicals with alkyl and peroxide radicals during styrene oxidation. Russ J Phys Chem B. 2012;6:376-83.

20. Haibo Wang, Yujing Jia, Peng Gao, Ying Cheng, Min Cheng, Chengtao Lu, Siyuan Zhou, Xiaoli Sun. Synthesis, radioprotective activity and pharmacokinetics characteristic of a new stable nitronyl nitroxyl radical-NIT2011. Biochimie. 2013;95:1574-81.

21. Chateauneuf J, Lusztyk J, Ingold KU. Absolute rate constants for the reactions of some carbon-centered radicals with 2,2,6,6tetramethylpiperidine-N-oxyl. J Org Chem. 1988;53:1629-32.

22. Samuni A, Mitchell JB, DeGraff W, Krishna CM, Samuni U, Russo A. Nitroxide SOD-mimics: modes of action. Free Radic Res Commun. 1991;12/13:187-94.

23. Augusto O, Trindade DF, Linares E, Vaz SM. Cyclic nitroxides inhibit the toxicity of nitric oxide-derived oxidants: mechanisms and implications. An Acad Bras Cienc. 2008;80:179-89.

24. Braunhut SJ, Medeiros' D, Lai L, Bump EA. Tempol prevents impairment of the endothelial cell wound healing response caused by ionising radiation. Br J Cancer. 1996;74(Suppl XXVII):S157-60.

25. Hahn SM, Krishna MC, DeLuca AM, Coffin D, Mitchell JB. Evaluation of the hydroxylamine Tempol-H as an in vivo radioprotector. Free Radic Biol Med. 2000;28:953-8.

26. Mitchell JB, Degraff W, Kaufman D, Krishna MC, Samuni A, Finkelstein E, Ahn M, Hahn SM, Gamson J, Russo A. Inhibi- tion of oxygen-dependent radiation-induced damage by the nitroxide superoxide dismutase mimic, Tempol. Arch Biochem Biophys. 1991;289:62-70.

27. Hahn SM, Tochner Z, Krishna CM, Wilson L, Samuni A, Venzon D, Glatstein E, Mitchell JB, Russo A. Tempol a stable free radical is a novel, murine radioprotector. Cancer Res. 1992:52:1750-3.

28. Jiang J, Stoyanovsky DA, Belikova NA, Tyurina YY, Zhao Q, Tungekar MA, Kapralova V, Huang Z, Mintz AH, Greenberger JS, Kagan VE. A mitochondriatargeted triphenylphosphonium-conjugated nitroxide functions as a radioprotector/mitigator. Radiat Res. 2009;172:706-17.

29. Jiang J, Belikova NA, Hoye AT, Zhao Q, Epperly MW, Greenberger JS, Wipf P, Kagan VE. A mitochondria-targeted nitroxide/hemigramicidin S conjugate protects mouse embryonic cells against gamma irradiation. Int J Radiat Oncol Biol Phys. 2008;70:816-25.

30. Alley MC, Scudiero DA, Monks A, Hursey ML, Czerwinski MJ, Fine DL, Abbott BJ, Mayo JG, Shoemaker RH, Boyd MR. Feasibility of drug screening with panels of human tumor cell lines using a microculture tetrazolium assay. Cancer Res. 1988:48:589-601.

31. Belikova A, Jiang J, Stoyanovsky DA, Glumac A, Bayir H, Greenberger JS, Kagan VE. Mitochondria-targeted (2-hydroxyamino-vinyl)-triphenylphosphonium releases NO. and protects mouse embryonic cells against irradiation-induced apoptosis. FEBS Lett. 2009;583:1945-50.

32. Pollard JM, Reboucas JS, Durazo A, Kos I, Fike F, Panni M, Gralla EB, Valentine JS, Batinic-Haberle I, Gatti RA. Radioprotective effects of manganese-containing superoxide dismutase mimics on ataxiatelangiectasia cells. Free Radic Biol Med. 2009;47:250-60.

33. Behbahani $H$, Rickle $A$, Concha $H$, Ankarcrona M, Winblad B, Cowburn RF. Flow cytometry as a method for studying effects of stressors on primary rat neurons. J Neurosci Res. 2005;82:432-41.

34. Guo J, Zhang Y, Zeng L, Liu J, Liang J, Guo G. Salvianic acid A protects L-02 cells against_-irradiation-induced apoptosis via the scavenging of reactive oxygen species. Environ Toxicol Pharmacol. 2013;35:117-30.

35. Janero DR. Malondialdehyde and thiobarbituric acid-reactivity as diagnostic indices of lipid peroxidation and peroxidative tissue injury. Free Radic Biol Med. 1990;9(6):515-40.

36. Amit Kumar D, Deepti B, Vineet K, Chawla D, Fakhruddin K, Deepak B. Antioxidant potential and radioprotective effect of soy isoflavone against gamma irradiation induced oxidative stress. J Funct Foods. 2012:4:197-206.

37. Halliwell B, Gutteridge JMC. Free radical in biology and medicine. 2nd ed. Oxford: Clarendon; 1989

38. Ward JF. DNA damage produced by ionizing radiation in mammalian cells: identities, mechanisms of formation, and reparability. Prog Nucleic Acid Res Mol Biol. 1988;35:95-125
39. Kalpana KB, Devipriya N, Srinivasan M, Menon VP. Investigation of the radioprotective efficacy of hesperidin against gamma-radiation induced cellular damage in cultured human peripheral blood lymphocyte. Mutat Res. 2009:676:54-61.

40. Samuni AM, DeGraff W, Cook JA, Krishna MC, Russo A, Mitchell JB. The effects of antioxidants on radiation-induced apoptosis pathways in TK6 cells. Free Radic Biol Med. 2004;37:1648-55.

41. Samuni AM, Barenholz Y. Stable nitroxide radicals protect lipid acyl chains from radiation damage. Free Radic. Biol. Med. 1997;22:1165-74.

42. Hahn SM, Wilson L, Krishna CM, Liebmann J, DeGraff W, Gamson J, Samuni A, Venzon D, Mitchell JB. Identification of Nitroxide Radioprotectors. Radiat Res. 1992;132:87-93.

43. Metz JM, Smith D, Mick R, Lustig R, Mitchell J, Cherakuri M, Glatstein E, Hahn SM. A phase I study of topical tempol for the prevention of alopecia induced by whole brain radiotherapy. Clin Cancer Res. 2004;19:6411-7.

44. Fraternale A, Paoletti MF, Casabianca A, Nencioni L, Garaci E, Palamara AT, Magnani M. GSH and analogs in antiviral therapy. Mol Aspects Med. 2009; 30:99-110.

45. Pocernich CB, La Fontaine M, Butterfield DA. In-vivo glutathione elevation protects against hydroxyl free radical-induced protein oxidation in rat brain. Neurochem Int. 2000;36:185-91.

46. Pompella A, Visikis A, Paolicchi A, De Tata V, Casini AF. The changing faces of glutathione, a cellular protagonist. Biochem Pharmacol. 2003;66:1499-503.

47. Fang $Y Z$, Yang $S$, Wu G. Free radicals, antioxidants, and nutrition. Nutrition. 2002;18:872-9.

48. Reed DJ, Fariss MW. Glutathione depletion and susceptibility. Pharmacol Rev. 1984;36:235-335.

49. DeGraff WG, Mitchell JB. Glutathione dependence of neocarzinostatin cytotoxicity and mutagenicity in Chinese hamster V-79 cells. Cancer Res. 1985;45:4760-2.

50. Coppola S, Ghibelli L. GSH extrusion and the mitochondrial pathway of apoptotic signalling. Biochem Soc Trans. 2000;28:56-61.

51. Zhang Y, Guo J, Qi Y, Shao Q, Liang J. The prevention of radiation-induced DNA damage and apoptosis in human intestinal epithelial cells by salvianic acid A. J Radiat Res Appl Sci. 2014;7:274-85.

52. Zhu C, Hallin U, Ozaki Y, Grandér R, Gatzinsky K, Bahr BA, Karlsson JO, Shibasaki F, Hagberg H, Blomgren K. Nuclear translocation and calpaindependent reduction of $\mathrm{BCl}-2$ after neonatal cerebral hypoxia-ischemia. Brain Behav Immun. 2010;24(5):822-30.

53. Croker BA, O'Donnell JA, Nowell CJ, Metcalf D, Dewson G, Campbell KJ, Rogers KL, Hu Y, Smyth GK, Zhang JG, White M, Lackovic K, Cengia LH, O'Reilly LA, Bouillet P, Cory S, Strasser A, Roberts AW. Fas-mediated neutrophil apoptosis is accelerated by Bid, Bak, and Bax and inhibited by Bcl-2 and Mcl-1. Proc Natl Acad Sci U S A. 2011:108(32):13135-40.

54. Jee YH, Jeong WI, Kim TH, Hwang IS, Ahn MJ, Joo HG. P53 and cell-cycleregulated protein expression in small intestinal cells after fast-neutron irradiation in mice. Mol Cell Biochem. 2005;270:21-8.

55. Parihar VK, Jatin D, Kumar S, Manjula SN, Subramanian G, Unnikrishnan MK, Mallikarjuna Rao C. Free radical scavenging and radioprotective activity of dehydrozingerone against whole body gamma irradiation in Swiss albino mice. Chem Biol Interact. 2007;170:9-58.

56. Samuni A, Krishna CM, Mitchell JB, Collins CR, Russo A. Superoxide reaction with nitroxides. Free Radic Res Commun. 1990;9:241-9.

57. Samuni A, Krishna CM, Riesz P, Finkelstein E, Russo A. A novel metal-free low molecular weight superoxide dismutase mimic. J Biol Chem. 1988;263:17921-4.

58. Krishna MC, Grahame DA, Samuni A, Mitchell JB, Russo A. Oxoammonium cation intermediate in the nitroxide-catalyzed dismutation of superoxide. Proc Natl Acad Sci U S A. 1992;89:5537-41.

59. Krishna MC, Russo A, Mitchell JB, Goldstein S, Dafni H, Samuni A. Do nitroxide antioxidants act as scavengers of $\mathrm{O}_{2}^{--}$or as SOD mimics? J Biol Chem. 1996:271:26026-31.

60. Miura Y, Utsumi H, Hamada A. Antioxidant activity of nitroxide radicals in lipid peroxidation of rat liver microsomes. Arch Biochem Biophys. 1993;300:148-56.

61. Krishna MC, Samuni A, Taira J, Goldstein S, Mitchell JB, Russo A. Stimulation by nitroxides of catalase-like activity of hemeproteins: kinetics and mechanism. J Biol Chem. 1996;271:26018-25.

62. Mitchell JB, Russo A, Kuppusamy P, Krishna MC. Radiation, radicals, and images. Ann N Y Acad Sci. 2000;899:28-43. 